\title{
Citizens Inclusion in the Political Decision-Making Process as a Determinant of Sustainable Development Implementation
}

\author{
Alina Kaszkur ${ }^{1}$ and Izabela Kapsa ${ }^{1}$
}

\begin{abstract}
All efforts to involve the society in the affairs of local communities are an important aspect of the implementation of the principle of sustainable development. Citizen's involvement in decision making processes not only positively correlates with their sense of action, but also affects the quality of decisions made by public authorities which gain the opportunity to learn more about the needs and expectations of citizens. The best conditions for the implementation the principle of sustainable development, basing on the dialogue with citizens, are on local level - in the cities. Moreover, using new information and communication technologies opens a number of possibilities to even more fully activation of local communities. As a consequence, the residents have greater impact on the quality of political decisions, that take into account their needs and expectations, it is also a chance to improve the quality of their life. The main research goal of the article is to answer the question what characterizes sustainable development of the city and how the use of information and communication technologies by public authorities may affect a more complete implementation of the principle of sustainable development. The research method is an analysis of the documents and source materials.
\end{abstract}

Keywords: civic engagement, e-participation, information and communication technologies, local authorities, sustainable development of the cities

\section{Introduction}

The modern understanding of the concept of sustainable development goes beyond the narrow economical and environmental meaning, pointing out to further areas of human activity in which sustainability is both an indicator of growth and a source of innovation. In the context of political activity, the goal is to ensure responsive, inclusive, participatory and representative decision-making at all levels, emphasizing the importance of public access to information, protection of fundamental freedoms and the promotion of non-discriminatory laws and policies for sustainable development (Global Sustainable Development Report 2016). The 2030 Agenda calls for transparent, effective, inclusive and accountable institutions to advance poverty eradication and sustainable development.

Increasing citizen participation in the public sphere by including them in the decisionmaking processes positively correlates with their feeling of self-agency. Citizens gain the opportunity to articulate their needs and expectations. Thanks to this, the government receives information regarding their real problems, which in turn may increase the effectiveness of local problem-solving. Active participation also entails the possibility of controlling the content of political decisions. Engagement and the feeling of impactfulness and self-agency translated to the improved quality of citizens' life and 
contributes to the realization of the principles of sustainable development. Therefore, creating appropriate conditions and enforcing both the individual and collective activities of citizens becomes the main role of the state and its agendas. In this sense the individual, secured by the right for inclusion in decision-making and the right for healthy and productive growth, becomes an active entity in social and economical processes (Woźniak, 2015, p. 84).

New ICT technologies bring a plethora of possibilities connected with including citizens in the decision-making processes. The authors of the present article assume that cities provide the best conditions for realizing the principles of sustainable development on the basis of dialogue with citizens, including the use of ICT. The main research goal of the article is to answer the question - what characterizes sustainable development of the city and how the use of information and communication technologies by public authorities may affect a more complete implementation of the principle of sustainable development. The article has been divided into sections. The first section describes the concept of sustainable development in the aspect of cities. The second one discusses the procedure of including citizens in decision-making processes as a fundamental feature of modern democracy. Afterwards, we enumerate examples of including citizens in the decisionmaking processes in cities. These include numerous tools and forms of including citizens in the process of political decision-making. While many of these examples relate to Poland, they are also used by other local authorities in Europe and other parts of the world. In fact, they were often introduced in other countries and have been, through practice and positive experiences, applied and successfully used in Poland as well. This is the reason why the concluding section discusses implications for public administration and policy, as further growth and adjustments of tools to the local conditions is a challenge faced by modern democracy. The main research method is an analysis of the documents and source materials.

\section{The Concept of Sustainable Development in the Aspect of Cities}

The idea of sustainable development, in the meaning with which it is commonly associated today, was introduced in the mid 1980s due to the publication of the World Commission on Environment and Development report called Our Common Future (1987), in which sustainable development was defined as one, in which the needs of the present generation should be satisfied without decreasing the chances of satisfying the needs of future generations.

At first the notion of sustainable development has been related mainly to the matters of limiting the negative impact of human activities on nature. In time, its definition has been broadened - beside natural environment, the components of society and economy also have been distinguished, with the emphasis of keeling balance between all three components.

People started using the notion of sustainable development worldwide in 1992, after the Earth Summit in Rio de Janeiro. According to Agenda 21 (1992) sustainable development was understood as a growth process which unconditionally links the needs of present generations with the ability to satisfy the needs of future generations. The notion was simultaneously defined as a series of changes, in which the use of resources, investment 
profiles, the direction of technological process, as well as institutional structures ought to be introduced without clashes between current and future needs. (Sztumski, 2006, p. 73). The notion of sustainable development is also included in the legislation of many states, including Poland - Article 5 of the Constitution of the Republic of Poland (1997). This concept may be realized particularly well in local conditions. This is the reason why we should reflect upon sustainable development also in the context of cities.

As indicated by Mierzejewska (2015, pp. 6-7), in the context of sustainable development, cities require an integrated approach, encompassing the social, economical and ecological aspects as well as considering spacial and institutional aspects. However, in this respect it is also assumed that none of the spheres of human activity should develop at the expense of the remaining ones. City-related models and concepts of sustainable development may be essentially divided into two groups. The first group consists of those that relate to spacial forms of cities. The second one, however, encompasses those that relate to the quality of life in a city, especially in the context of social justice and sustainable civic economy. According to a different criterion the first group relates to the organization of an inner spacial-functional and socio-economical structure of a city. Whereas the second group pertains to organizing relations between a city and its region.

Bearing in mind that modern cities are inhabited by more than half of the world's population, they have a tremendous developmental potential, but also many social, economical and spacial issues. Each day, city councils face a great challenge - how to govern cities in a sustainable way. Alongside thinking about economic efficiency, it is also important to be able to perceive a city as a social organism in which individual groups and institutions form mutual interactions and social engagement and trust gain in importance (Kaszkur, 2017, p. 59).

A sustainable development is particularly demanding of enhanced participation in decision-making (Meadowcroft, 2004, p. 168), as advocated by the following arguments: (1) with respect to deliberately orientating social change, participation can be understood as both a democratic imperative (as a guarantee that social actors will have some say in the direction of movement); and as a management strategy in order to identify the needs and make appropriate actions (2) with respect to the normative content of sustainable development, participation can facilitate a more complete disclosure of existing attitudes, the juxtaposition of different approaches, and the transformation of values; (3) with respect to the encompassing nature of the project, it can promote the integration of knowledge, and the adaptation of governance to the diverse cross-cutting contexts relevant to sustainable development; (4) with respect to „learning through doing”, participation can promote adaptive management and knowledge acquisition by societal partners and governments.

\section{Including Citizens in Decision-Making Processes as a Fundamental Feature of Modern Democracy}

The modern model of democracy is based on the contribution of citizens in the process of making political decisions. Even though formally democratic states largely function in the form of representative democracy, tools enabling direct citizen participation are being used more and more often in the process of political decision- 
making. The evolution of the Internet as the basic medium of modern communication, being not only a one-way instrument for sharing content, but most importantly a twoway interaction, caused that the familiar democratic model has been enriched both by new tools and social groups engaged in democratic processes. This is arguably the right way, as it contributes to fighting the crisis of democracy, in which decreasing trust to political decision-makers, the inability to influence the content of political decisions and finally the isolation of the public sphere have all caused the troubling phenomenon of social anomie. As it was correctly observed by Putnam (2000), a society was spending less and less time in collective social or political behaviours. Thus, it may be assumed that similar to other aspects of human life, improved communication in the public sphere will have a positive impact on relations. Numerous researchers are currently interested in this phenomenon. Some of them evaluate and measure a range of Internet and social media communication with the goal to determine ways they encourage widespread access, dissemination, and deliberation on community issues (Kavanaugh et al., 2014). Others claim that the demands of participation in various international regimes makes policy coordination across government a key factor in determining effective and inclusive governance at national level (Zubcevic, 2016, p. 62-63). Others take it a step further, assuming that the use of ICT and CMC in all types of media in order to strengthen political democracy or citizen participation in the democratic process leads to digital democracy (van Dijk, Hacker, 2000, p. 1). Its aim is quite close to what Jurgen Habermas and John Rawls called deliberative democracy, based on multi-faceted interactions between the governing and those governed or the idea of liquid democracy which combines the principles of direct democracy and representative democracy.

Both researchers and practitioners of public administration agree to the need of developing and implementing mechanisms for citizen involvement in decision-making. It is amicably acknowledged that stakeholder collaboration, communication, and participation have now emerged as characteristics and essential elements of local governance (Hawkins, Wang, 2012, p. 12), as the local level is the most propitious to the development of civic participation. The smaller the community is, the bigger is its participation in the process of making political decisions. In such a community, democratic and inclusive relationships between people, in family structures and communities, play an important role in fostering the experience of citizenship for people living in poverty and marginalisation (Shahrokh, 2015, p. 17). The process of including citizens pertains not only to the conscious and active social groups, but also those that were excluded from civic activity. The change of relations between people and the creation of spaces for expressing citizenship with others help people in recognising and fighting for their rights. The classic concept of ,ladder of citizen participation”, developed by Arnstein (1969, in: Shahrokh, 2015, p. 12), contains the degrees of citizen empowerment that corresponds to levels of involvement. The assumption is that greater levels of involvement increase its effectiveness. Thus, it may be concluded that a collaborative and participatory approach to policy development produces more just and equitable outcomes and is more functional than a top-down method of decision-making. Examples of such an approach will be provided below. 


\section{Examples of Including Citizens in the Decision-Making Processes in Cities}

Literature on the subject includes many papers indicating that collaboration and participation by stakeholders in decision making, particularly by local residents, is critical for successful plan development and project implementation (Hawkins, Wang, 2012, p. 8). In this day and age, universal use of information and communication technologies plays an increasingly larger role in helping communities share information and in fostering interaction and communication among local residents, government, voluntary associations and other organizations. At one hand the local governments limit themselves only to sharing information electronically, at the other they reach for various interaction tools, which forces us to distinguish a couple of levels civic engagement in the process of decision-making. The OECD: Citizens as Partners (2001) report indicates that democratic political participation must include ways of being informed, mechanisms of participation in the decision-making process and the ability to participate in and have an influence on a political program. This was included in the following three requirements: (1) information, i.e. a one-way relation in which the government creates and provides information to the citizens; (2) consultation i.e. a two-way relation in which citizens share their feedback with the government; (3) active participation, i.e. a two-way relation based on cooperation between citizens and the government, in which they are actively engaged in the political process. The influence that citizens may have on the shape of politics rises with each subsequent level of participation. By contrast, Zubcevic (2016, p. 64) enumerates four forms of engagement: (1) communication and awareness raising; (2) consultation; (3) involvement in decision-making; (4) involvement in various parts of implementation and progress reviews. Assuming that information is the most passive of these forms, below are examples of active inclusion of citizens in the decisionmaking process.

Public consultations on a local level are practised optionally or compulsorily in order to obtain the citizens' opinion on a given subject, e.g. an investment, building renovations or road repairs. The right to consultations in Poland is guaranteed by the so-called local government acts (the Municipality Government Act from 8 March 1990, the Poviat Government Act from 5 June 1998, and the Voivodeship Government Act from 5 June 1998). Consultations are conducted compulsorily in matters related to changing borders of a poviat or municipality and precede the issuing of a Regulation of the Council of Ministers (Ura, 2012, pp. 216-217). The most commonly consulted matters are development and spacial plans, determining networks of schools, creating cooperation programmes with non-government organizations, environment protection programmes and creating municipal strategies for solving social problems (Theiss, 2012, p. 74). Public consultations are beneficial because citizens may present their opinions and expectations towards settling certain matters. This may prevent making many incorrect decisions that are often caused by the lack of full and current understanding of the population's expectations. Admittedly, the results of such consultations are not binding, but have a significant political impact, as they reflect the sovereign's standpoint (Rachwal, 2011, p. 127). More and more often public consultations are conducted on-line. This applies mostly to large cities. In smaller cities only the information regarding their date and place are published on the Internet, whereas citizen need to either personally come to a 
meeting or sign and send their opinions to the appropriate office.

Participatory budgets are regarded as good practice in terms of active participation of citizens, as both the best projects and proposals for their realizations are chosen by the citizens, not the city councils. The Brazilian city of Porto Alegre was the first to introduce his kind of budget in 1989 and it was adopted by six European cities in the year 2000. Currently there are over 100 of these, mainly in Spain, Portugal, France and Great Britain. The most commonly known European metropolises that use this type of budgeting are: Lisbon, Paris, Rome, London, Seville, Cordoba and Berlin. In Poland, participatory budgets were introduced in 2003-2005 and since 2019 are compulsory in cities with poviat rights. However, in none of the Polish cities does it apply to the entire available budget, but only at minimum 0,5\% (as per the updated Act from 11 January 2018). What is curious, on-line voting is being increasingly used in the process of casting votes for projects proposed within participatory budgets. This seems to be significant because of the fact that in Poland there is practically no debated on the possibility to cast votes on-line in the general elections, even though such a tool exists. The biggest advantages of participatory budget are the following: clear and transparent management of public money and also financing of those public investments that have not been noticed by officials beforehand. Another positive effect that this form of democracy has is the citizens' increasing contribution to the life of the local community as well as growing responsibility for the city's development. Moreover, local authorities are evaluated positively and their legitimization increases, even though it is preceded by long and heavily involved dialogue with the society.

Spacial planning is a particularly significant matter in the context of sustainable development. The spacial planning model of a sustainable city should be based on respecting resources and the harmonization of ecological, economical and social development goals (Lorens, 2013, p. 12). Crucially, the needs of citizens should also be considered. Thus, local authorities must also stimulate participation in the processes of planning and developing urbanisation activities in such a way that city spaces become widely available and attractive for all social groups. New ICT technologies are also used more and more frequently in this respect. Moreover, trust to their adaptation for the purposes of realising activities in the public sphere, both among decision-makers and citizens, is increasing as well.

To conclude this section, it is worth describing a few examples of a positive use of technology in the process of consultations and political decision-making, even though they are used rather sparingly. Broader use of these tools is on one hand a challenge, but on the other an opportunity for improved inclusion of citizens in the decision-making processes. One of such tools is the German platform LiquidFeedback (used on a city level in Friesland, a region of the Federal Republic of Germany), which is used as tool for sharing proposals and the direction of politics of the region to the local community. These are then put to a vote by all the users of the system. The application also servers an informative function - local authorities use it as a means of informing citizens of their decisions. In Spain, smaller political parties use the Agora Voting tool. It is a software program used for voting which enables conducting safe and procedurally clear elections. Another example from this country is the Appgree application, first used by the Podemos party in 2015, when it decided to bring up its political program for discussion 
and voting in an open-source system. Since its launch, the application enabled a high level of participation and now it is the recommended tool in participatory budget processes (Glab, Pares, 2015, p. 53). Due to its gigantic participatory potential - users can log in both from their PCs and mobile devices - the application may encourage citizens to participate in the budgeting, as it removes the restrictions related to unavailability at a given time and place. Another example that is worth describing is the Virtual Town Square (VTS) project. As indicated by its authors, Andrea Kavanaugh, Siddarth Krishnan, Manuel Pérez-Quiñones, John Tedesco, Kumbirai Madondo and Ankit Ahuja (2014, p. 36), even though we universally use the Internet nowadays, small communities frequently do not benefit from the advances in the technologies for the web. Such services are dedicated to large social groups and not designed to address the unique challenges faced by small and rural communities. The main motivation for creating VTS was to enable citizens of local communities to reflect and deliberate on local issues, by aggregating news and information articles from websites of local organizations such as newspapers, community groups, universities and governments; weblogs of individuals and groups, and exchanges on social media. According to its authors it encourages participation on other sites, but at the same time has social affordances to support discussion and interaction among local citizens.

And interesting method which joins the characteristics of voting and deliberation with the use of new technologies is the 21st century town meeting. Used to discuss local and state affairs, it enables leading discussions in small groups and simultaneously making group decisions. Participants work in moderated 10-man groups that may be located in different places. The moderator, using the Internet (or sometimes special applications), sends the group's ideas to a central point. These are summarized by a special team and sent back to the participants, who can comment and vote on them on-line, viewing the results almost instantly. This method is applied, for example, in the planning process and also during formulating politics. It has been used to determine the final shape of the reconstruction of Ground Zero in New York or New Orleans after hurricane Katrina (Przywojska, 2016, pp. 113-114). Another tool that might be used in planning processes is Geoankieta. It is a web-based platform for giving anonymous opinions regarding a consulted area. Consultation tools which are transferred to the virtual sphere foster gathering experiences and visions about a given area. Crucially, Geoankieta may reach a relatively small number of users. It is important, however, to give participating citizens proper information regarding the project along with a description of its location (citizen participation).

An equally interesting solution, used by the authorities in Warsaw in 2015 in creating a long-term vision for the city's development with the citizens' input, was the Warszawa2030 project. As part of this project, the citizens of Warsaw, had the opportunity, via a website, to share their vision of the city's future in the perspective of the next 15 years. Furthermore, the site offered them various other forms of taking action in the creation of their vision of the city's future. They could, for example, use Minecraft of create a film and the best projects were rewarded. Via the website, the citizens could also collectively edit a futuristic story of Warsaw called Futurestory. As a result, a collaborative vision of Warsaw's future has been formed (\#Warszawa2030). 


\section{Conclusions}

Contemporary democracies, mature governments and modern leaders accept the need of including citizens in political processes. Whereas citizens have the ability to use numerous forms of participating in public life. Thanks to the use of modern communication tools many of these forms are simpler, faster and requires less investments than the traditional methods. Citizen engagement is also paramount in realising the notion of sustainable development. During the past decades, sustainable development has increasingly been accepted as an objective of government policy in the developed countries. The successful balancing of economic, social and environmental goals is understood as central to this project (Meadowcroft, 2004, p. 163). This understanding of the idea led to the creation of the Sustainable Development Governance concept - a model based on the influence of Citizen Participation, along with and in relation to Capacity and Management (assisted by a support network), on Local Activities (Hawkins, Wang, 2012, p. 11). According to its authors, participatory governance produces programs and policies that can be implemented, whereas participation enhances meaningful interactions, facilitates learning and education and builds trust in the authorities. Research shows that one mechanism to support information exchange as well as to help carry out and implement local initiatives is through boards and commissions established by the city. Nearly $53 \%$ of the cities in our sample indicated that these mechanisms are utilized to support citizen participation in sustainable development.

Sustainable development must be planned accordingly and realized by all entities within a city - local authorities, citizens, business entities non-government organizations or associations (Mierzejewska, 2015, p. 6). Its main goals include shaping a high quality of life, both for the current and the future generations. In the context of sustainable development, this quality relates to overall living conditions of a person or group, shaping in social, economic, environmental and awareness aspects in the development of a given area which, in an objective and subjective sense, make up our feeling of fulfilling our needs and life goals in a given place and time (Zadrożniak, 2015, p. 31). In this aspect it is important for the individuals to able to communicate their needs and codecide on matters that are important to them, gaining the feeling of real influence on their surrounding reality and processes.

Societies are showing increasing awareness of their subjectivity. This is the root of their claims to be included in political processes. By accommodating these expectations, legislators create various participation-enabling institutions such as: social bodies with advisers, referenda, consultations-discussions, workshops, panels - all the while using more and more new ICT technologies. Using them, participating citizens may show their preferences and interests, influencing politics and the way how authority functions (Szlachetko, 2017, p. 45). Civic engagement means acting in order to change a given community's civic life and to develop knowledge, abilities, qualities and motivation to implement this change. This entails promoting a community's quality of life, both using political and non-political methods (Ekman, Amnå, 2012, p. 269). As mentioned before, new ICT technologies have the potential to increase the level of participation. This is affirmed by examples of good practices of their use, described in the present article. New 
technologies are also a chance to participate for those that have been excluded, either due to health-related problems or their age and can no longer participate in public matters in a traditional sense.

Cities need the knowledge and wisdom of their citizens as well as highly effective solutions which will help in generating social prosperity and sustainable economic development, and, in consequence, foster improving quality of life of their citizens (Laska, 2017, p. 13). Bearing in mind that cities accumulate most expectations and needs, it is worth using the newest technologies, especially in terms of including citizens in the processes of consultations and political decision-making. Without engagement and participation of citizen in the decision-making process any development strategies that are being formulated in cities might be misguided.

\section{Acknowledgement}

Paper prepared under the project: E-voting jako alternatywna procedura głosowania w elekcjach państwowych. Doświadczenia wybranych państw a perspektywy wdrożenia e-głosowania w Polsce [E-voting as an alternative voting procedure in state elections. Experience of selected countries and the perspectives of e-voting implementation in Poland]: UMO-2014/15/B/HS5/01358 (NCN, OPUS programme).

\section{References}

\#Warszawa2030. (2019, June 22). Retrieved from http:/ /otwartawarszawa.pl/warszawa2030/

21 st century town meeting. (2019, June 22). Retrieved from https://partycypacjaobywatelska.pl/strefawiedzy/techniki/21st-century-town-meeting/

Agenda 21. (1992). United Nations Conference on Environment \& Development Rio de Janerio. Brazil.

Citizens as Partners. (2001). OECD Handbook on Information, Consultation and Public Participation in Policy-Making, Paris: OECD Publication Service.

Ekman, J., Amnå, E. (2012). Political participation and civic engagement: towards a new typology. Human Affairs, vol. 22, pp. 283-300.

Geoankieta. (2019, June 23). Retrieved from https://partycypacjaobywatelska.pl/strefawiedzy/techniki/geoankieta/

Glab, V., Parés, M. (2015). Narzędzia ICT w procesach budżetu partycypacyjnego. Warszawa: Fundacja Pracownia Badań i Innowacji Społecznych „Stocznia”.

Hacker, K.L., van Dijk, J. (2000). Digital Democracy: Issues of Theory and Practice. London: SAGE Publications Ltd.

Hawkins, Ch., Wang, X. (2012). Sustainable Development Governance Citizen Participation and Support Networks in Local Sustainability Initiatives. Public Works Management \& Policy, vol. 17(1), pp. 7-29.

Kapsa, I. (2018). Elektroniczna partycypacja obywatelska w miastach typu „smart”. Doświadczenia Polski na tle innych państw. In: A. Kaszkur, A. Laska (eds.). Innowacyjność w warunkach wspótczesnych miast (pp. 78-99). Bydgoszcz: Wydawnictwo UKW.

Kapsa, I., Kaszkur, A., Sierzputowska, A. (2018). Contemporary City as a Subject of Research: A MultiFaceted Analysis. Proceedings of The 5 th International Conference on Research in Behavioral and Social Science, Barcelona: Diamond Scientific Publication.

Kaszkur, A. (2017). Innowacyjne formy partycypacji na poziomie lokalnym w Polsce. In: A. Kaszkur, A. Laska (ed.). Innowacyjność w warunkach wspótczesnych miast (pp. 59-77). Bydgoszcz: Uniwersytet Kazimierza Wielkiego.

Kavanaugh, A., Krishnan, S., Pérez-Quiñonesa, M., Tedesco, J., Madondod, K., Ahuja, A. (2014). Encouraging civic participation through local news aggregation. Information Polity, vol. 19, pp. 3556. 
Kuropatwa, A. (2011). Budżet partycypacyjny - prezentacja, egzemplifikacja i ocena idei. In: M. Winiarski (ed.). Gospodarka: innowacje i rozpój (pp. 51-62). Wrocław: Instytut Nauk Ekonomicznych Wydziału Prawa, Administracji i Ekonomii.

Laska, A. (2017). Idea smart city - miedzy innowacyjnością publiczną a technokratycznym zagrożeniem. In: A. Kaszkur, A. Laska (ed.). Innowacyjność w warunkach wspótçesnych miast (pp. 13-31). Bydgoszcz: Uniwersytet Kazimierza Wielkiego.

Lorens, P. (2013). Równoważenie rozwoju przestrzennego miast polskich. Gdańsk: Wydział Architektury Politechniki Gdańskiej.

Meadowcroft, J. (2004). Participation and sustainable development: Modes of citizen, community and organisational involvement. In: W. Lafferty (ed.) Governance for Sustainable Development: The Challenge of Adapting Form to Function (pp. 162-190). Northampton: Edward Elgar.

Mierzejewska, L. (2015). Zrównoważony rozwój miasta - wybrane sposoby pojmowania, koncepcje i modele. Problemy Roz̨woju Miast. Kwartalnik Naukony Instytutu Roz̨woju Miast. Rok XII, Zeszyt II, pp. 5-11.

Putnam, R. (2000). Bowling alone: The collapse and revival of American community, New York: Simon \& Schuster.

Przywojska, J. (2016). Rewitalizacja miast. Aspekt społeczny. Lódź: Uniwersytet Lódzki.

Rachwał, M. (2011). Konsultacje społeczne z mieszkańcami gminy jako forma partycypacji politycznej. In: B. Lewenstein, M. Dudkiewicz (eds.). Lokalny dialog obywatelski. Refleksje i doświadczenia (pp. 115-127). Warszawa: Uniwersytet Warszawski.

Report of the World Commission on Environment and Development: Our Common Future. (1987).

Shahrokh, T. (2015). Collective action and participatory research as strategies toward citizen-led accountability. In: D. Burns, P. Ikita, E. Lopez Franco, T. Shahrokh (eds.), Citizen participation and accountability for sustainable development (pp. 6-17). Brighton: Institute for Development Studies.

Szlachetko, J.H. (2017). Partycypacja społeczna w lokalnej polityce przestrzennej. Warszawa: Wolters Kluwer.

Sztumski, W. (2006). Idea zrównoważonego rozwoju a możliwości jej urzeczywistnienia. Problemy Ekorožoju, vol. 1, no 2, pp. 73-76.

The Constitution of The Republic of Poland of 2nd April, 1997. As published in Dziennik Ustaw No. 78, item 483.

Theiss, M. (2010). System pozornie otwarty. O instytucjonalnych uwarunkowaniach lokalnej partycypacji politycznej w Polsce. In: B. Lewenstein, J. Schindler, R. Skrzypiec (eds.). Partycypacja spotecżna i aktywizacja w rozwiazywaniu problemón spoteczności lokalnych (pp. 61-80). Warszawa: Uniwersytet Warszawski.

Ura, E. (2012). Konsultacje w sprawie zmiany granic gminy jako forma partycypacji obywateli w rozstrzyganiu spraw publicznych (na przykładzie Rzeszowa - miasta na prawach powiatu. In: M. Stec, M. Mączyński (eds.). Partycypacja obywateli i podmiotów obywatelskich w podejmowaniu rozstraygniéć publicznych na poziomie lokalnym (pp. 216-229). Warszawa: Wolters Kluwer.

Ustawa z dnia 8 marca 1990 r. o samorządzie gminnym. (1990). Dz.U. $1990 \mathrm{nr} 16$ poz. 95.

Ustawa z dnia 5 czerwca 1998 r. o samorządzie powiatowym. (1998). Dz.U. $1998 \mathrm{nr} 91$ poz. 578.

Ustawa z dnia 5 czerwca 1998 r. o samorządzie województwa. (1998). Dz.U. 1998 nr 91 poz. 576.

Ustawa z dnia 11 stycznia 2018 r. o zmianie niektórych ustaw w celu zwiększenia udziału obywateli w procesie wybierania, funkcjonowania i kontrolowania niektórych organów publicznych. (2018). Dz.U. 2018 poz. 130.

Woźniak, Z. (2015). Cykliczne badania jakości życia narzędziem wsparcia miejskiej strategii rozwoju. Ruch prawniczy, ekonomiczny $i$ socjologiczny LXXVII (1), pp. 79-99.

Zubcevic, I. (2016). Inclusive Institutions for Sustainable Development. Global Sustainable Development Report 2016. New York: United Nations.

Zadrożniak, M. (2015). Jakość życia w kontekście koncepcji zrównoważonego rozwoju. Acta Universitatis Lodriensis Folia Oeconomica, vol. 2 (313), pp. 21-36. 